\title{
PENGUATAN KELUARGA SAKINAH BAGI IBU MUDA DI KECAMATAN UMBULHARJO KOTA YOGYAKARTA
}

\section{Desy Aniqotsunainy dan Nurhapsari Pradnya Paramytha}

Sekolah Tinggi Agama Islam Masjid Syuhada Yogyakarta email: desyaniqo@yahoo.com

\section{Abstrak}

Penelitian ini adalah program pengabdian masyarakat yang secara khusus difokuskan pada penguatan keluarga sakinah bagi ibu muda dan character building sebagai model kegiatan peningkatan pendidikan keagamaan di Kecamatan Umbulharjo. Berangkat dari Kondisi yang menjadi fokus masih tingginya angka perceraian di Kota Yogyakarta adalah Kecamatan Umbulharjo yang merupakan daerah perkotaan dari tahun ke tahun menunjukkan angka tertinggi dibanding kecamatan lainnya di kota Yogyakarta.

Penelitian ini adalah participatory action research (PAR) yaitu penelitian yang ditindaklanjuti dengan aksi penguatan keluarga sakinah bagi ibu muda di kecamatan Umbulharjo, dengan pengumpulan data menggunakan metode observasi dan wawancara, kemudian untuk data sekunder yang berupa catatan dan pelaporan program peningkatan pendidikan perkawinan daerah sasaran, diperoleh dengan cara penelusuran data di wilayah penelitian.

Hasil pengabdian fokus pada tindakan dalam upaya merintis model penguatan keluarga sakinah dengan membangun kesadaran melalui terbukanya ruang dialog antara pandangan ibu muda yang kontraproduktif terhadap tujuan pernikahan,menjadi pandangan-pandangan yang lebih positif untuk terciptanya keluarga sakinah. Pada akhirnya kerja sama sinergis dalam upaya memberikan stimulus, agar ada model penguatan keluarga sakinah dari sisi konsep, dan adanya program pembinaan pasca menikah sehingga, ibu-ibu muda akan dioptimalkan fungsinya agar menjadi center integrated community development.

Kata kunci : Perkawinan, Keluarga, Sakinah, Model Penguatan

\section{Abstract}


Desy A. dan Nurhapsari : Penguatan Keluarga Sakinah Bagi Ibu Muda

This study is a community service program that is specifically focused on strengthening the harmonious family for young mothers and character building as a model of religious education improvement activities in the District Umbulharjo. Departing from the condition that the focus of the high divorce rate in the city of Yogyakarta District of Umbulharjo which are urban areas from year to year shows the highest number compared to other districts of the city.

This study is a participatory action research (PAR) is the research followed by action strengthening harmonious family for young mothers in the district Umbulharjo, with data collection using the method of observation and interviews, then to secondary data such as records and reporting program to improve education marital target area, Data obtained by the search in the area of research.

Results devotion focused on the action in an effort to strengthen harmonious family models pioneered by building awareness through open space for dialogue between the views of young mothers that are counterproductive to the goal of marriage, views more positive for the creation of a harmonious family. At the end of synergic cooperation in order to provide stimulus, so existing models harmonious family strengthening of the concept, and their coaching program post-marry so, young mothers will be optimized functions to be integrated community development center.

Keywords : Marriage, Family, Sakinah, strengthening models

\section{Pendahuluan}

\section{Isu dan Fokus Pengabdian}

Islam mengajak manusia untuk hidup dalam naungan keluarga. Keluarga merupakan miniatur kehidupan sebagai salah satu alternatif solusi pemenuhan keinginan manusia tanpa menghilangkan kebutuhannya. Tujuan utama menikah menurut Al-Qur'an ialah terciptanya keadaan keluarga sakinah, mawaddah wa 
Desy A. dan Nurhapsari : Penguatan Keluarga Sakinah Bagi Ibu Muda

rahmah antara suami, isteri dan anak-anaknya,1 sebagaimana firman Allah :

"dan di antara tanda-tanda kekuasaan-Nya ialah Dia menciptakan untukmu isteri-isteri dari jenismu sendiri, supaya kamu cenderung dan merasa tenteram kepadanya, dan dijadikan-Nya diantaramu rasa kasih dan sayang. Sesungguhnya pada yang demikian itu benar-benar terdapat tanda-tanda bagi kaum yang berfikir.2 (Ar-Rum ayat 21)

Bentuk persetujuan dari sebuah pernikahan Islam berupa kesepakatan suami isteri memikul kewajiban luhur untuk menegakkan keluarga sakinah, mawaddah wa rahmah yang menjadi sendi dasar dari susunan suatu masyarakat. Sebelum memasuki dan membentuk rumah tangga, calon suami istri harus mempersiapkan diri secara matang baik rohani maupun jasmani. Pasangan suami istri memahami prinsip-prinsip yang terkandung dalam hukum Islam tentang perkawinan serta azas-azas perkawinan menurut UU Nomor 1 Tahun 1974, sehingga terbentuk keluarga harmonis.

Berdasar hasil penelitian awal penulis, kondisi rumah tangga di lapangan bebeda jauh dengan kondisi ideal tujuan pernikahan. Banyak keluarga memilih cerai sebagai solusi alternatif penyelesaian konflik keluarga. Masyarakat tidak sadar banyak efek yang dapat timbul pasca perceraian, terutama bagi keluarga yang sudah memiliki anak. Anak menjadi korban utama perpecahan keluarga. Anak hasil perceraian cenderung menjadi broken home dan seringkali memilih jalan yang salah.

Rahmat Hakim, Hukum Perkawinan Islam untuk IAIN, STAIN, PTAIS, cet. ke-I (Bandung: Pustaka Setia, 2000), hlm. 15

Departemen Agama RI, Al-Qur'an dan Terjemahnya, (Surabaya: Surya Cipta Aksara,1993), hlm. 644 
Desy A. dan Nurhapsari : Penguatan Keluarga Sakinah Bagi Ibu Muda

Masyarakat yang paham essensi pernikahan masih sedikit. Masyarakat melakukan pernikahan layaknya sebuah budaya, mengikuti tren artis karena pernikahan artis terlihat indah cantik. Di sisi lain banyak terjadi pernikahan dini yang mana pelaku pernikahan belum matang secara psikologis. Masyarakat yang demikian cenderung sulit melakukan manajemen konflik, karena latar belakang pendidikan dan pemahaman mengenai essensi pernikahan belum dimiliki. Kondisi demikian yang memberikan akibat tingginya tingkat perceraian di Indonesia.

Menurut Sudibyo Alimoeso selaku Deputi KSPK BKKBN mengatakan bahwa tingginya, data perceraian di Indonesia menjadi perihal serius karena keluarga merupakan pendidikan pertama yang meletakkan dasardasar kepribadian, etika, dan moral anak-anak.3 Tingginya angka perceraian mengisyaratkan terjadi persoalan dalam hubungan perkawinan. Kondisi tersebut, menurut Asniar Khumas mengutip pendapat Hachstaff mengakibatkan perceraian menjadi bagian dari budaya yang diyakini dan dipraktekkan keluarga-keluarga Amerika, yang mendefinisikan budaya perceraian sebagai keyakinan bahwa perkawinan adalah pilihan dan perceraian adalah jalan keluar.

Berdasarkan penelitian Asniar Khumas (seorang psikolog Universitas Negeri Makasar) terdapat beberapa faktor intensi bercerai yaitu faktor pendidikan, semakin tinggi tingkat pendidikan seorang istri, intensi cerainya semakin rendah. Berdasar penelitian tersebut Pendamping 
Desy A. dan Nurhapsari : Penguatan Keluarga Sakinah Bagi Ibu Muda

tertarik untuk melakukan Penguatan keluarga sakinah mawaddah wa rahmah bagi Ibu muda usia pernikahan 1-5 tahun agar sinergis dalam mengurangi atau bahkan memutus rantai tingginya angka perceraian di Kota Yogyakarta. Sejalan dengan latar belakang di atas, masalah pokok dalam penelitian ini adalah Bagaimanakah kondisi pernikahan ibu muda di wilayah kecamatan Umbulharjo? Selanjutnya masalah ini dibatasi menjadi dua bagian :

a. Bagaimana pemahaman ibu muda di kecamatan Umbulharjo tentang makna dan tujuan pernikahan?

b. Bagaimana model penguatan keluarga sakinah di wilayah kecamatan Umbulharjo?

Secara akademik penelitian ini diharapkan dapat menemukan solusi terhadap persoalan di Masyarakat Yogyakarta dengan meningkatkan peran strategis keluarga. Adapun secara praktis penelitian ini memiliki signifikansi berikut :

a. Teridentifikasinya aspirasi dan kebutuhan masyarakat khususnya ibu-ibu muda di wilayah Umbulharjo agar memiliki peran lebih dari berbagai aspek, salah satunya penguatan keluarga sakinah sebagai input perubahan pemahaman, sikap dan keterampilan demi terwujudnya keluarga sakinah.

b. Dengan penelitian ini dapat mengubah pemahaman, sikap dan perilaku ibu-ibu muda yang tidak kondusif, ke arah penguatan keluarga sakinah sebagai rule model dalam masyarakat. Dengan adanya penelitian sekaligus pengabdian masyarakat ini setidaknya dapat bermanfaat bagi masyarakat terutama perubahan terhadap pemahaman keluarga sakinah ke arah yang lebih baik. 
Desy A. dan Nurhapsari : Penguatan Keluarga Sakinah Bagi Ibu Muda

Membina kerjasama serta mempertahankan relasi sosial yang baik antara masyarakat, KUA, BP4 dan dan pemerintah Kecamatan Umbulharjo maupun pihak terkait lainnya.

Bagi peneliti lain, agar mampu membuat penelitian terkait dengan upaya penguatan keluarga sakinah dalam aspek yang lebih luas.

Peneliti, lebih kreatif dan jeli dalam membuat penelitian bukan hanya memaparkan dan menciptakan teori tentang model penguatan keluarga sakinah, tetapi dapat memberikan solusi dari persoalan yang terjadi dalam keluarga pernikahan usia 1-5 tahun.

\section{Alasan Memilih Subjek Dampingan}

Hasil penelitian pendahuluan yang dilakukan beberapa hari di Kecamatan Umbulharjo Kota Yogyakarta, dapat dipaparkan kondisi kehidupan masyarakatnya sebagai berikut;

Pertama, Perceraian di Kecamatan Umbulharjo yang merupakan daerah perkotaan dari tahun ke tahun menunjukkan angka tertinggi dibanding kecamatan lainnya di kota Yogyakarta. Data menunjukkan bahwa rata-rata umur perempuan cerai hidup adalah 44,6 tahun. Sebagian besar (92,9 persen) bekerja dan mereka berpendidikan rendah. Pada umumnya anak-anak hasil perkawinan dengan mantan suami tinggal bersama perempuan cerai. Mayoritas umur tua cenderung tidak ingin menikah lagi. Juga menunjukkan pada umumnya perempuan cerai mempunyai kondisi sosial ekonomi yang relatif rendah (37,2 persen) dan sedang (39,8 persen). 
Desy A. dan Nurhapsari : Penguatan Keluarga Sakinah Bagi Ibu Muda

Kedua, Luas wilayah Kecamatan Umbulharjo yang hampir sepertiga luas wilayah Kota Yogyakarta menyimpan potensi tersendiri. Artinya bahwa diperlukan energi lebih guna mewujudkan tata pemerintahan yang baik. Termasuk wilayah Kecamatan Umbulharjo yang berbatasan langsung dengan wilayah Kabupaten Bantul mempunyai ciri tersendiri khususnya kawasan aglomerasi perluasan kota.

\section{Tujuan}

Tujuan penelitian ini diantaranya :

a. Terjalin komunikasi dan koordinasi antara Perguruan Tinggi STAIMS dangan stakeholder terkait diantaranya KUA Kecamatan Umbulharjo, BP4 Kota Yogyakarta.

b. Program penguatan keluarga sakinah berlangsung secara kontinu dan berkesinambungan.

Menurunnya tingkat perceraian di wilayah Umbulharjo.

\section{B. Kerangka Konsep}

\section{Gambaran Umum Lokasi Pengabdian}

Umbulharjo adalah sebuah kecamatan di Kota Yogyakarta, Provinsi Daerah Istimewa Yogyakarta, Indonesia. Kecamatan ini merupakan kecamatan terluas di kota Yogyakarta. Kecamatan Umbulharjo Kota Yogyakarta adalah merupakan salah satu Kecamatan dari 14 Kecamatan di Kota Yogyakarta yang terletak di sisi Selatan Kota Yogyakarta dengan ketinggian dari permukaan laut 113 M dengan Luas Wilayah+811,4800 Ha yang berbatasan dengan :

a. Sebelah Barat: Kecamatan Mergangsan, Kecamatan Pakualaman 
Desy A. dan Nurhapsari : Penguatan Keluarga Sakinah Bagi Ibu Muda

b. Sebelah Timur : Kec. Kotagede, Kec. Banguntapan Kab.Bantul

c. Sebelah Selatan : Kabupaten Bantul

d. Sebelah Utara : Kecamatan Gondokusuman

Luas wilayah Kecamatan Umbulharjo yang hampir sepertiga luas wilayah Kota Yogyakarta menyimpan potensi tersendiri. Artinya bahwa diperlukan energi lebih guna mewujudkan tata pemerintahan yang baik. Termasuk wilayah Kecamatan Umbulharjo yang berbatasan langsung dengan wilayah Kabupaten Bantul mempunyai ciri tersendiri khususnya kawasan aglomerasi perluasan kota.

Secara administratif berdasarkan SK Gubernur DIY Nomor : 48/KPTS/ 1985 tanggal 22 Februari 1985, wilayah Kecamatan Umbulharjo terdiri dari 7 Kelurahan, yaitu: Keluarahan Semaki, Keluarahan Muja-muju, Kelurahan Tahunan, Kelurahan Warungboto, Kelurahan Pandeyan, Kelurahan Sorosutan dan Kelurahan Giwangan. Terdiri dari 326 Rt dan 83 RW. Jumlah penduduk Kecamatan Umbulharjo pada tahun 2015 sebanyak 67.651 jiwa.

\section{Kondisi Dampingan yang Diharapkan}

Berdasarkan beberapa fakta di atas, maka ada beberapa hasil atau output yang diharapkan dari kondisi dampingan adalah sebagai berikut :

a. Peningkatan pemahaman ibu muda di wilayah kecamatan Umbulharjo dalam menerapkan konsep keluarga sakinah untuk terbentuknya keluarga sebagai center integrated community development secara berkelanjutan.

b. Berkembangnya strategi penguatan keluarga sakinah yang lebih bervariatif sehingga meningkatkan kualitas 
Desy A. dan Nurhapsari : Penguatan Keluarga Sakinah Bagi Ibu Muda

keluarga sakinah bagi ibu muda usia pernikahan 1-5 tahun yang berkelanjutan

c. Terbangunnya jaringan komunikasi antara ibu muda dengan masyarakat serta dengan bantuan para lembaga social keagamaan seperti BP4 dapat memberikan bimbingan penasehatan tentang perkawinan secara berkelanjutan.

\section{Strategi Pelaksanaan}

Dosen di Perguruan Tinggi memberikan bantuan teknik, dengan memberikan pelatihan

Pelatihan penguatan keluarga sakinah oleh Dosen Pendamping yang mempunyai keahlian di bidang penasehatan Perkawinan

Memberikan pelatihan dan bimbingan pemahaman tentang aspek-aspek hak dan kewajiban perempuan dalam pernikahan, pendidikan perkawinan dan character building yang bertujuan memberikan penguatan bagi ibu muda.

Penerbitan Modul terkait penguatan keluarga sakinah

\section{Kajian Teori}

Perkawinan

1) Pengertian perkawinan

Konsep perkawinan memiliki arti dari berbagai sudut pandang, secara yuridis definisi perkawinan di atur dalam Undang-undang No. 1 Tahun 1974 Pasal 1 (dalam Walgito, 2000), perkawinan adalah ikatan lahir batin antara seorang laki-laki dan seorang perempuan sebagai suami istri dengan tujuan membentuk keluarga (rumah tangga) yang bahagia dan kekal berdasarkan Ketuhanan Yang Maha Esa. Menurut Gunarsa dan Gunarsa (2007), 
Desy A. dan Nurhapsari : Penguatan Keluarga Sakinah Bagi Ibu Muda

perkawinan merupakan kesatuan dua individu laki-laki dan perempuan menjadi satu kesatuan yang saling mencintai, saling menginginkan kebersamaan, saling membutuhkan, saling memberi dukungan, saling melayani, kesemuanya diwujudkan dalam kehidupan yang dinikmati bersama.

Berdasarkan uraian di atas dapat disimpulkan bahwa perkawinan adalah suatu ikatan yang sah antara seorang laki-laki dan seorang perempuan sebagai sepasang suami istri untuk berjanji hidup bersama-sama dan saling mengisi dalam pemenuhan kebutuhan biologis maupun psikologis serta selalu berusaha saling menciptakan dan mempertahankan kebahagiaan dan keharmonisan perkawinan sehingga tujuan dan harapan yang diinginkan dapat tercapai.

2) Tujuan perkawinan

Menurut Walgito (2000), suami istri perlu saling membantu dan melengkapi agar masing-masing dapat mengembangkan kepribadiannya mencapai kesejahteraan spiritual dan material. Menurut Kusnadi (2005) tujuan bersama dalam perkawinan adalah komposisi dari setiap tujuan personal pasangan yang mungkin dengan cara kooperatif akan menyertakan kedua keinginan pasangan tersebut, apabila kedua keinginan tersebut terkandung dalam satu tujuan bersama sebagai hasil akhir.

Berdasarkan uraian di atas dapat disimpulkan bahwa tujuan perkawinan adalah untuk menciptakan hidup rumah tangga yang sejahtera bersama pasangan yang menjadi pilihan dan untuk meneruskan keturunan 
Desy A. dan Nurhapsari : Penguatan Keluarga Sakinah Bagi Ibu Muda

pada umumnya dalam membina keluarga yang bahagia bersama pasangannya sampai akhir waktu.

3) Tahap-tahap kehidupan perkawinan

Tahap-tahap dalam perkawinan perlu diketahui agar mengerti tentang konsep perjalanan hidup pasangan serta masa-masa krisis yang dialaminya. Walgito (2000), terdapat tiga periode dalam perkawinan yaitu : a. Tahun awal (early years). Masa ini mencakup kurang lebih 10 tahun pertama perkawinan. Masa ini merupakan masa perkenalan dan masa penyesuaian diri bagi kedua belah pihak, pasangan suami istri berusaha untuk saling mengenal, menyelesaikan sekolah atau memulai karier, merencanakan kehadiran anak pertama serta mengatur peran masingmasing dalam menjalani hubungan suami istri tahuntahun pertama biasanya sangat sulit untuk dilalui karena pasangan muda ini tidak dapat mengantisipasi ketegangan atau tekanan yang mungkin timbul. Angka perceraian tertinggi terjadi antara tahun kedua sampai tahun keempat pekawinan. ; b. Tahun pertengahan (midlle years). Periode ini berlangsung antara tahun kesepuluh sampai dengan tahun ketigapuluh dari masa perkawinan. Masa yang terjadi pada tahap ini adalah "child full phase" yang kemudian diikuti oleh "us aging phase". Pada "child full phase" orangtua mengkonsentrasi-kan pada pengembangan dan pemeliharaan keluarga, selain itu suami istri harus mampu menyelesaikan konflik-konflik sosial yang timbul dalam perkawinan, sehingga tidak terjadi ketegangan dalam keluarga. Pada "us aging phase" pasangan suami istri menemukan dan membangun kembali hubungan antara kedua belah pihak. Pasangan 
Desy A. dan Nurhapsari : Penguatan Keluarga Sakinah Bagi Ibu Muda

suami istri kembali menyusun prioritas baru dan menikmati hubungan intim yang telah diperbaharui, tanpa ada anak-anak dalam rumah; c. Tahun matang (mature years). Masa ini dimulai pada tahun ketiga puluh dalam perkawinan. Pasangan suami istri berada dalam peran yang baru, misalnya bertindak sebagai kakek atau nenek, menikmati hari tua bersama-sama atau hidup sendiri lagi karena salah satu pasangan telah meninggal lebih dulu. Masa ini merupakan masa pensiun atau pengunduran diri dari kegiatan-kegiatan di dalam dunia kerja.

Perkawinan menuju keluarga sakinah

Pengertian Keluarga Sakinah

Istilah keluarga sakinah merupakan dibentuk oleh dua suku kata, yakni kata keluarga dan kata sakinah. Secara etimologi (kebahasaan), keluarga dalam kamus besar bahasa Indonesia mempunyai artian :Ibu,bapak dengan anak-anaknya; Orang seisi rumah yang menjadi tanggungan, batih.4 Undang-undang Nomor 1 tahun 1974 tentang perkawinan pada pasal 1 disebutkan : "Perkawinan ialah ikatan lahir batin antara seorang laki-laki dan seorang perempuan sebagai suamiisteri dengan tujuan membentuk keluarga atau rumah tangga yang bahagia dan kekal berdasarkan agama dan kepercayaannya masing-masing. 5

Istilah sakinah secara etimologis (bahasa) disebutkan sebanyak enam kali dalam Al-quran seperti tertulis pada buku ensiklopedi Islam. Pengungkapan Al-

Pusat penyusunan dan pengembangan bahasa, Kamus besar bahasa Indonesia, (Balai Pustaka, Cet.3, jakarta, 1990), hlm. 667.

Ismail Widjaja, (ed.), Panduan KB. Mandiri, (PT. Falwa Arika, Jakarta, 1987), hlm. 125 
Desy A. dan Nurhapsari : Penguatan Keluarga Sakinah Bagi Ibu Muda

Qur'an itu jelas disebutkan bahwa sakinah itu memiliki arti ketentraman, ketenangan, kedamaian, rahmat, dan tuma'ninah yang berasal dari Allah SWT. Seperti terurai pada QS. Al-Baqarah :248 Kemudian dalam QS. Baraaah : 26 yang berarti tentram.

Kemudian dalam QS. Al-Fath : 4 yang berarti tentram. Yang artinya : Dia-lah yang telah menurunkan ketenangan ke dalam hati orang-orang mukmin supaya keimanan mereka bertambah di samping keimanan mereka (yang telah ada). dan kepunyaan Allah-lah tentara langit dan bumi[1394] dan adalah Allah Maha mengetahui lagi Maha Bijaksana.6

Secara terminologis (istilah) ungkapan tentang sakinah dalam Al-Qur'an muncul beberapa pengertian. Ali bin Muhammad al-Jurjani (w.816 H /1413 M), ahli pembuat kamus-kamus ilmiah, menyebutkan bahwa sakinah adalah adanya ketentraman dalam hati pada saat datangnya sesuatu yang tak diduga, dibarengi satu nur (cahaya) dalam hati yang memberi ketenangan dan ketentraman dalam hati pada yang menyaksikannya dan merupakan pokok 'ain al-yaqin (keyakinan berdasarkan penglihatan).7 Pasal 3 KHI (Kompilasi Hukum Islam) disebutkan bahwa : "perkawinan bertujuan untuk mewujudkan kehidupan rumah tangga yang sakinah (tentram), mawaddah (penuh cinta) dan rohmah (penuh kasih sayang)."8

6 Yayasan Penyelenggara penterjemah/ penafsir, Al-Qur'an dan Terjemahnya, (Departemen Agama, 1986), hlm.830

7 Dewan penyusun ensiklopedi Islam, "Sakinah", EnsiklopediIslam,Cet.I, jilid I, 1993, hlm.202

Dadan Muttaqien dkk,Peradilan agama dan kompilasi hukum islam dalam tata hukum Indonesia, ( UII Press, Jogja, 1993) hlm. 67 
Desy A. dan Nurhapsari : Penguatan Keluarga Sakinah Bagi Ibu Muda

b) Metode Pembinaan Keluarga Sakinah

Bentuk perserikatan paling kecil, namun menentukan dalam masyarakat adalah "lembaga keluarga", atau biasa disebut rumah tangga. Suatu masyarakat akan baik kalau lingkungannya terdiri dari keluarga-keluarga yang bertanggung jawab. Sebaliknya, masyarakat akan rusak jika terdiri dari keluarga rusak. Mustahil suatu lembaga keluarga dapat serasi tanpa keharmonisan anggota-anggotanya sendiri, terutama kecocokan antara ayah dan ibu.

Rumah tangga islami adalah rumah tangga yang laksana surga bagi setiap penghuninya, tempat melepas lelah, tempat bersenda gurau, yang diliputi rasa bahagia, aman dan tentram, sebagaimana sabda Rasulullah SAW.: "Rumah tanggaku adalah Surgaku". Ibnu Musthafa menyarankan, hendaknya keluarga-keluarga Islam perlu memperbaiki diri dengan segera, dengan merenungkan kembali apa yang telah, sedang,dan akan terjadi. Keluarga muslim harus kembali kepada fitrahnya dan mengkaji ulang apa yang telah diperbuat yang telah menimbulkan kesengsaraan-kesengsaraan pribadi dan anak-anaknya. Kesadaran suami-istri akan fitrahnya masing-masing akan memungkinkan terbinanya kesejahteraan dan keseimbangan dalam keluarga Islam yang Sakinah, mawaddah dan warrahmah.9

Ibnu Musthafa, Keluarga Islam Menyongsong abad 21 (,Al-Bayan, Bandung, 1993), hlm. 110 
Desy A. dan Nurhapsari : Penguatan Keluarga Sakinah Bagi Ibu Muda

\section{Metodologi Penelitian}

a. Jenis penelitian

Penelitian ini dilakukan dengan menggunakan participatory action research (PAR). Action research adalah proses spiral yang meliputi perencanaan tindakan yang melibatkan investigasi yang cermat, kemudian pelaksanaan tindakan dilanjutkan penemuan fakta-fakta tentang hasil dari tindakan, serta penemuan makna baru dari pengalaman sosial. Lebih lanjut dikemukakan oleh Corey bahwa action research adalah proses dimana kelompok sosial berusaha melakukan studi masalah mereka secara ilmiyah dalam rangka mengarahkan dan memperbaiki, dan mengevaluasi keputusan dan tindakan mereka.10

Hopskins yang dikutip oleh Ahmad Mahmudi, dkk mengemukakan action research merupakan upaya mengkontribusi baik pada masalah praktis pemecahan masalah maupun pada tujuan ilmu sosial itu sendiri dengan mengkolaborasikan di dalamnya yang dapat diterima oleh kerangka kerja etik, sedangkan Peter Park menilai bahwa action research, merupakan cara penguatan masyarakat melalui penyadaran diri untuk melakukan tindakan yang efektif menuju perbaikan kondisi kehidupan mereka. 11

10 Mikkelsen, Metode Penelitian Partisipatoris dan Upaya Pemberdayaan; Panduan bagi Praktisi Lapangan, (Jakarta: Yayasan Obor Indonesia, 2011), hlm. 56-59

11 Ahmad Mahmudi, dkk, Penelitian Aksi Partisipatoris, sebuah Pengantar, (Yogyakarta: SUSDEC, 2003), hlm.7 
Desy A. dan Nurhapsari : Penguatan Keluarga Sakinah Bagi Ibu Muda

Tahapan-tahapan pelaksanaan PAR

Tahapan pelaksanaan dilakukan sebagai berikut : a) Tahap persiapan sosial/awal; b) Identifikasi data dan fakta social; c) Analisa social; d) Perumusan masalah social; e) Mengorganisir gagasan; f) Merumuskan rencana; g) Pengorganisasian sumber daya; h) Aksi untuk perubahan; i) Observasi evaluasi; j) Refleksi

Teknik pengumpulan data

Dalam pengumpulan data ini mengacu pada metodologi penelitian PAR secara umum. Teknikteknik yang dimaksud sebagai berikut :

a) Wawancara mendalam kepada pihak terkait; Focus Group Discussion (FGD); c) Data sekunder yang diperoleh dari informasi yang dipublikasikan oleh lembaga berkepentingan seperti Kantor KUA Kecamatan Umbulharjo, media cetak, media elektronik maupun literatur.

Pengolahan dan analisa data

Data yang ditemukan selanjutnya dianalisis dengan teknik-teknik:

Membuat pohon analisis masalah dan pohon analisis tujuan. Analisis ini menurut Ahmad Mahmudi disebut sebagai pohon analisis masalah dan pohon analisis tujuan dalam materi short course tentang metode penelitian Participatory Action Research.

Membuat matriks analisis partisipasi dan rencana aksi bersama masyarakat. 
Desy A. dan Nurhapsari : Penguatan Keluarga Sakinah Bagi Ibu Muda

Pihak-pihak yang terlibat dan bentuk keterlibatannya Dalam menjalankan program ini akan melibatkan beberapa pihak diantaranya :

Kantor Urusan Agama (KUA) Kecamatan

Umbulharjo Kota Yogyakarta

Badan Penasehat Pembinaan dan Pelestarian

Perkawinan (BP4) Kota Yogyakarta.

Pakar Kesehatan Masyarakat yang ada di Kota

Yogyakarta yang fokus dalam Character Building.

\section{Pembahasan}

\section{Kondisi Masyarakat Dampingan}

Wilayah Umbulharjo terdiri dari tujuh kelurahan yang dihuni 67.651 orang yang terdiri dari 30.915 orang belum menikah dan 32.355 orang telah menikah. Sedangkan berdasarkan jenis pekerjaan masyarakat Umbulharjo cermin masyarakat perkotaan beraneka ragam. Sebagian besar penduduk berprofesi sebagai buruh, pada tingkat kedua merupakan pegawai pemerintahan dan tingkat ketiga memiliki profesi sebagai pedagang.

Data perkawinan di kecamatan Umbulharjo sebanyak 388 jiwa dengan 5 kasus perkawinan di bawah umur. Pernikahan di bawah umur menjadi permasalahan sendiri, karena pada kasus pernikahan di bawah umur cenderung belum memahami makna pernikahan sehingga kemungkinan angka perceraian cukup tinggi.

Berdasarkan kasus pembinaan di wilayah KUA Umbulharjo, terdapat 388 jumlah pembinaan perkawinan, 31 pembinaan karena kasus perselisihan. Dari jumlah kasus perselisihan yang dibina oleh KUA hanya $10 \%$ kasus 
Desy A. dan Nurhapsari : Penguatan Keluarga Sakinah Bagi Ibu Muda

yang dapat diselesaikan secara kekeluargaan. Sedangkan 90\% kasus berakhir dengan perceraian. Hal ini menunjukkan bahwa masyarakat datang ke KUA sebagai alternatif terakhir dalam menghadapi problema rumah tangga.

\section{Perencanaan Program}

Program penguatan keluarga sakinah bagi ibu muda di Kecamatan Umbulharjo Kota Yogyakarta, diarahkan dalam rangka upaya untuk memberikan pemahaman kepada ibu muda tentang pentingnya pendidikan perkawinan secara berkesinambungan pasca menikah 1-5 tahun, dan secara langsung memberikan masukan tentang sikap open minded bagi para ibu muda terhadap tujuan keluarga sakinah menurut perspektif islam.

Untuk memulai kegiatan pengabdian banyak hal yang digali dari ibu-ibu muda di wilayah kecamatan Umbulharjo, tidak saja dari tim kelompok tetapi juga pihak-pihak terkait dengan ibu-ibu muda usia pernikahan 1-5 tahun. Sejak awal tim pengabdian sudah melakukan survey awal yang dilakukan sebelum mengajukan proposal pengabdian. Tujuan dilakukannya survey tersebut untuk memastikan apakah ibu muda pasca pernikahan 1-5 tahun perlu didampingi atau tidak.

Berdasarkan survey yang dilakukan oleh tim pengabdian masyarakat sebanyak tiga kali ke lokasi, maka dipandang perlu untuk didampingi, karena dari pengamatan sekilas bahwa ibu muda yang usia pernikahannya 1-5 tahun belum ada pembinaan pasca nikah, sehingga sangat potensial untuk melakukan 
Desy A. dan Nurhapsari : Penguatan Keluarga Sakinah Bagi Ibu Muda

pendampingan sebagai salah satu cara terwujudnya keluarga sakinah.

Sehubungan dengan itu tim pengabdian memulai berbagai kegiatan yang sudah disusun secara sistematik seperti yang tertulis di dalam proposal pengabdian,. Tema utama dari pengabdian ini adalah berupa penguatan keluarga sakinah bagi ibu muda di Kecamatan Umbulharjo kota Yogyakarta.

Perencanaan dilakukan dengan melakukan assesment (penilaian awal), dengan melakukan identifikasi dan inventarisasi serta mapping dengan lembaga, instansi dan masyarakat di kecamatan Umbulharjo, terkait untuk mengetahui potensi yang dimiliki oleh masyarakat Umbulharjo khususnya Ibu Muda. Untuk penilaian awal tim pengabdian memetakan kondisi perkawinan, dengan melakukan observasi dan dokumentasi untuk melihat kondisi dilapangan secara langsung, mulai dari kantor KUA kecamatan Umbulharjo untuk memperoleh data ibu muda usia pernikahan 1-5 tahun. Setelah itu tim pengabdi meneruskan perjalanan untuk melihat kondisi lokasi, mulai dari mendatangi tempat tinggal ibu muda, jarak lokasi dengan tempat pelatihan yang strategis.

Tahapan selanjutnya dalam transek awal ini tim pengabdian juga menjalin komunikasi dan konsultasi dengan baik BP4, selaku badan pembinaan, penasihatan, perkawinan Kota Yogyakarta untuk mengetahui permasalahan-permasalahan yang terjadi karena banyaknya konsultasi pasangan yang menginginkan perceraian, sehingga perlu mediasi BP4 sebelum ke pengadilan agama. BP4 merupakan organisasi social 
Desy A. dan Nurhapsari : Penguatan Keluarga Sakinah Bagi Ibu Muda

kemasyarakatan di bawah Departemen Agama yang mempunyai visi terwujudnya kualitas keluarga sakinah, mawaddah,warahmah. Selama menjalin komunikasi tim pengabdian akhirnya sepakat dengan BP4 untuk samasama mendukung peningkatan kualitas pendidikan perkawinan sehingga wujud kerjasama ini tertuang dalam MOU (Memorandum of Understanding) antara STAI Masjid Syuhada yang ditanda tangani oleh Ketua STAIMS yaitu Dra $\mathrm{Hj}$. Sutinah dengan Ketua BP4 Kota Yogyakarta yang ditanda tangani oleh Drs. H. Anwar Sanusi MA.

Kemudian pelaksanaan identifikasi dan inventarisasi informasi diperoleh dengan melakukan wawancara langsung dengan Ibu muda di Kecamatan Umbulharjo. Kegiatan ini dilakukan dalam rangka menggali berbagai data yang terkait dengan obyek-obyek, kejadian, proses dan hubungan masyarakat yang dihasilkan dari transek, terutama terkait pemahaman ibu muda tentang makna keluarga sakinah.

Berdasarkan wawancara langsung maka diperoleh berbagai pemahaman dari ibu muda tentang pemahaman keluarga sakinah pasca menikah 1-5 tahun. Seperti kurangnya pemahaman hak dan kewajiban perempuan dalam perspektif islam, tujuan dan ciri-ciri keluarga sakinah serta pembangunan karakter dalam kehidupan keluarga. Dengan kurangnya pemahaman ibu muda pasca menikah tentang keluarga sakinah, menjadikan peluang bagi tim pengabdian untuk berusaha mengembangkan aspek pendidikan perkawinan sehingga terjadinya penguatan keluarga menuju sakinah mawaddah warahmah. 
Desy A. dan Nurhapsari : Penguatan Keluarga Sakinah Bagi Ibu Muda

\section{Perencanaan tindakan}

Langkah inisiatif yang dilakukan adalah penyampaian program kepada masyarakat bahwa program ini bertujuan agar eksistensi keluarga tetap terjaga. Dengan harapan peserta pendampingan dapat menjadi pilot project setelah pasca nikah bagi ibu rumah tangga sebagai salah satu upaya penurunan tingkat perceraian.

Pada tahap selanjutnya dilaksanakan focus grup discussion (FGD) baik dengan lingkar inti maupun dengan stakeholder terkait. Tujuan FGD ini adalah mengidentifikasi kebutuhan dasar peserta dampingan. Hasil preliminary research, sebagai langkah perencanaan tindakan dalam program penguatan keluarga sakinah, tim pengabdian memetakan pemahaman calon peserta program dan memetakan permasalahan-permasalahan yang seringkali timbul dalam keluarga. Rumusan permasalahan keluarga yang muncul diantaranya : Kurangnya pemahaman terhadap tujuan pernikahan, kurangnya kemampaun dalam pengelolaan konflik rumah tangga, kurangnya pemahaman tentang keluarga sakinah menurut ajaran Islam, kurangnya komunikasi antar pasangan sehingga kadang menimbulkan konflik.

Berdasarkan masukan-masukan, asumsi-asumsi penting di atas, juga pertimbangan keterbatasan waktu dan pendanaan, serta keadaan nyata di lapangan yang terkait. Maka disusunlah sasaran umum perencanaan tindakan sebagai berikut :

Program Pelatihan dengan tema Penguatan Keluarga

Sakinah Di Kecamatan Umbulharjo kota Yogyakarta dengan sasaran Sebagai sampel masyarakat, peneliti 
Desy A. dan Nurhapsari : Penguatan Keluarga Sakinah Bagi Ibu Muda

memilih 21 ibu muda dengan rentang usia pernikahan 1-5 tahun dari beragam tingkat pendidikan sebagai objek dampingan program penguatan keluarga sakinah. Konsep materi pelatihan sebagai berikut : 1) Hak dan kewajiban perempuan dalam perspektif islam; 2) Pendidikan perkawinan menuju keluarga sakinah;3) Pembangunan karakter keluarga sakinah Penyusunan modul pelatihan tentang penguatan keluarga sakinah, yang dalam jangka pendek.

\section{Pelaksanaan Tindakan}

Sesuai dengan rencana umum tindakan yang telah disusun bersama masyarakat, yang telah dilaksanakan dalam penelitian PAR, berkoordinasi dengan Ketua RW 04 Miliran Yogyakarta terkait pemakaian Gedung Balai Miliran, BP4 Kota Yogyakarta terkait Narasumber kegiatan dan melaksanakan rekruitmen pengisian biodata peserta yang meliputi : data nama calon peserta, umur, pendidikan, alamat.

Memperhatikan kondisi peserta maka tim mendapat data yang berupa usia pernikahan 1-5 tahun. Peserta pelatihan memiliki beragam latar belakang. Sebagian merupakan ibu rumah tangga, dan sebagian yang lain ialah ibu pekerja. Tingkat pendidikan peserta pelatihan juga beragam mulai dari lulus SD hingga perguruan tinggi. Memfasilitasi pelaksanaan pelatihan dengan jadwal dan materi pelatihan Pelatihan Keluarga sakinah diselenggarakan pada hari Sabtu, 29 Oktober 2016 berikut deskripsi pelaksanaan kegiatannya: a. Upacara pembukaan 
Desy A. dan Nurhapsari : Penguatan Keluarga Sakinah Bagi Ibu Muda

Acara ini dipandu oleh pengatur acara, yaitu Umam Mufthi, selanjunya pembacaan ayat suci AlQur'an dan kemudian menyanyikan lagu Indonesia raya. b. Materi Pelatihan Sesi Pertama

Materi tentang Hak dan Kewajiban Perempuan dalam perspektif islam disampaikan oleh Dailatus Syamsiyah, M.Ag. Pelatihan ini dilaksanakan dengan beberapa tahapan :

Sebelum pemateri memulai penjelasan materi, peserta diedarkan angket berupa pretest (awal tes) untuk mengetahui pengetahuan dasar sebelum peserta menerima materi.

Setelah itu penyampaian materi dengan pointers sebagai berikut :

Perempuan adalah makhluk penuh misteri, mysterium fascinorum atau misteri yang menawan menurut istilah Fuad Hasan mantan menteri P\&K era Orde Baru- mahluk kontroversial dan paling sulit dipahami sekaligus sering disalah-tafsirkan. Kontroversi tentang perempuan meliputi fungsi, peran dan bahkan pada sebutan kata "perempuan" itu sendiri. Dalam perspektif Islam, secara umum baik laki-laki maupun perempuan memiliki hak dan kewajiban yang sama yaitu : saling tolong-menolong, menyuruh orang lain berbuat ma'ruf sekaligus mencegah perbuatan munkar, sama-sama mendirikan salat, sama-sama mengeluarkan zakat, sama-sama mentaati Allah dan rasul-Nya (QS. Al-A'raf : 199). Tidak ada perbedaan balasan bagi laki-laki maupun perempuan dalam ketaatannya pada Allah. Allah 
berjanji menurunkan kasih-sayang-Nya kepada lakilaki dan perempuan yang beriman kepada Allah Swt, sudah disiapkan surga - tempat tinggal yang baik yang di dalamnya mengalir sungai-sungai. Itu semua merupakan rida Allah atas amal-amal yang mereka lakukan (Qs. At-Taubah : 71-72).

Setelah itu refleksi kepada peserta untuk menceritakan pengalaman pribadi maupun permasalahan yang dihadapi.

Setelah itu Posttes, yang bertujuan untuk mengetahui apakah ada perubahan pemahaman peserta anatar sebelum dan sesudah materi

Materi Pelatihan Sesi Kedua

Materi tentang Pendidikan Perkawinan Menuju Keluarga Sakinah, Mawaddah Warahmah disampaikan oleh Drs. H. Masykur,MA. Pelatihan ini dilaksanakan dengan beberapa tahapan :

Aktivitas awal pemateri pertama-tama menjelaskan kegiatan renungan dan disorientasi peserta artinya pemahaman awal peserta terhadap bahan renungan yang disampaikan fasilitator. Renungan dapat dilakukan terhadap: pemikiran, nilai, kemampuan, kekuatan, kelemahan, pengalaman, pelajaran yang diperoleh.

Setelah itu penyampaian materi dengan pointers sebagai berikut : Pendidikan perkawinan adalah sebuah proses pemahaman kepada orang tentang halhal yang terkaait dengan pernikahan, yang meliputi hukum perkawinan, tujuan pernikahan serta caracara untuk menuju keluarga yang sukses. 
Desy A. dan Nurhapsari : Penguatan Keluarga Sakinah Bagi Ibu Muda

Fungsi keluarga adalah spiritual : melaksanakan perintah allah, reproduksi : mendapatkan keturunan, sosial : berenteraksi intern dan antar anggota kelurga dan tetangga, ekonomi : menata ekonomi, pendidikan; rekreasi bersenang-senang, santai.

Setelah itu refleksi kepada peserta dengan metode tanya jawab

Materi Pelatihan Sesi Ketiga

Materi tentang character Building Indahnya membangun kebersamaan dalam keluarga disampaikan oleh Wuri Astuti, A.Md.Kes. Pelatihan ini dilaksanakan dengan beberapa tahapan :

Aktivitas awal pemateri pertama-tama dengan Diskusi berpasangan, dimulai dengan menjelaskan bahwa di awal suatu program pelatihan, peserta harus saling memperkenalkan diri dan mengenal satu sama lain dengan lebih baik. Fasilitator menekankan pentingnya seorang peserta mengenal dirinya sendiri dan peserta lain dalam pelatihan. Fasilitator menjelaskan proses perkenalan. Satu peserta bertanya dengan satu pertanyaan tentang identitas diri kepada peserta lain. Kemudian peserta lain menjawab sesuai apa yang ada dalam pikirannya sebanyak-banyaknya untuk menggambarkan tentang dirinya. Mintalah peserta untuk memperkenalkan mereka kepada peserta lain. Buatlah posisi berpasangan dan saling berhadapan antara peserta satu dengan peserta lain.

Refleksi

Fasilitator menanyakan apa yang diketahui peserta tentang hasil pertanyaan terhadap peserta 
Desy A. dan Nurhapsari : Penguatan Keluarga Sakinah Bagi Ibu Muda

lain, fasilitator mempertegas tentang pendidikan perkawinan menuju keluarga sakinah Di akhir sesi peserta diharapkan: lebih mengenal diri sendiri maupun peserta lain dalam menjelaskan dirinya sendiri secara spontan dalam satu pertanyaan.

Setelah itu penyampaian materi dengan pointers sebagai berikut :

Karakter atau tabiat watak seseorang terbangun melalui proses yang panjang dan memakan waktu maka sangat diperlukan kesabaran, ketelatenan dan konsistensi atau upaya yang sungguh-sungguh untuk mencapai/menjadikan diri mempunyai karakter yang ideal sehingga keluarga Sakinah Mawaddah Warrahmah dapat diwujudkan serta dapat menghantarkan anak-anak yang terlahir dalam rumah tangga sesuai tatanan norma-norma agama, budaya dan negara menjadi generasi penerus bangsa. Siap meneruskan estafeta kepemimpinan pada masanya kelak sebagai generasi yang berkualitas dan siap menghadapi tantangan zaman di era global. Refleksi dan dengan metode problem based learning

Fasilitator menguraikan studi permasalahan. Setelah tanggapan peserta dianggap cukup, fasilitator mempertegas tentang character building menuju kebersamaan keluarga sakinah

\section{Refleksi Tindakan}

Refleksi kegiatan selalu dilakukan setelah selesai tindakan dilaksanakan, tujuan dan refleksi ini adalah menemukan pengalaman baru selama proses pemberdayaan penelitian PAR, juga untk menggali 
Desy A. dan Nurhapsari : Penguatan Keluarga Sakinah Bagi Ibu Muda

kelemahan-kelemahan dari tindakan yang dilakukan sehingga dapat dilakukan perbaikan untuk tindakan berikutnya. Proses ini dilakukan secara langsung pada semua tindakan pemberdayaan yang dilakukan terhadap komunitas dampingan.

Temuan yang didapatkan selama proses refleksi terhadap program tindakan adalah sebagai berikut :

a. Penelitian ini menemukan latar belakang masalah bagi ibu muda usia pernikahan 1-5 tahun adalah kurangnya pemahaman tentang konsep keluarga sakinah dalam perspektif Islam, bukan hanya itu, tapi juga didorong oleh minimnya pembinaan pasca nikah yang dilakukan oleh lembaga social keagamaan maupun masyarakat.

b. Kurangnya pemahaman tentang konsep keluarga sakinah lahir diantaranya karena tingkat pendidikan yang rendah, lingkungan daerah perkotaan sehingga rata-rata suami istri bekerja, minimnya peran masyarakat dan lembaga keagamaan dalam pembinaan pasca nikah.

Hasil pemahaman ibu muda tentang hak dan kewajiban perempuan dalam perspektif islam menunjukkan peningkatan pemahaman dari sebelum (pretest). 
Desy A. dan Nurhapsari : Penguatan Keluarga Sakinah Bagi Ibu Muda

Tabel 1. Hasil Analisis Pretest Peserta

No Aitem

Alternatif Jawaban

Setuju Ragu-Ragu Tidak Setuju

$\begin{array}{clll}1 & 21(100 \%) & 0(0 \%) & 0(0 \%) \\ 2 & 20(95 \%) & 1(5 \%) & 0(0 \%) \\ 3 & 18(85 \%) & 2(10 \%) & 1(5 \%) \\ 4 & 20(95 \%) & 0(0 \%) & 1(5 \%) \\ 5 & 19(90 \%) & 2(10 \%) & 0(0 \%) \\ 6 & 18(85 \%) & 3(15 \%) & 0(0 \%) \\ 7 & 14(65 \%) & 4(20 \%) & 3(15 \%) \\ 8 & 20(95 \%) & 1(5 \%) & 0(0 \%) \\ 9 & 20(95 \%) & 1(5 \%) & 0(0 \%) \\ 10 & 16(75 \%) & 3(15 \%) & 2(10 \%) \\ \text { Jumlah } & 186 & 17 & 7 \\ \text { Rata-rata } & 89 \% & 8 \% & 3 \%\end{array}$

Kemudian setelah melalui pelatihan pemberian materi pelatihan berikut hasil post test peserta :

Tabel 2. Hasil Analisis Prosttest Peserta

\begin{tabular}{clll} 
No Aitem & \multicolumn{3}{c}{ Alternatif Jawaban } \\
& \multicolumn{1}{c}{ Setuju } & Ragu-Ragu & \multicolumn{1}{c}{ Tidak Setuju } \\
1 & $21(100 \%)$ & $0(0 \%)$ & $0(0 \%)$ \\
2 & $21(100 \%)$ & $0(0 \%)$ & $0(0 \%)$ \\
3 & $21(100 \%)$ & $0(0 \%)$ & $0(0 \%)$ \\
4 & $21(100 \%)$ & $0(0 \%)$ & $0(0 \%)$ \\
5 & $20(95 \%)$ & $0(0 \%)$ & $1(5 \%)$ \\
6 & $20(95 \%)$ & $1(5 \%)$ & $0(0 \%)$ \\
7 & $18(85 \%)$ & $1(5 \%)$ & $2(10 \%)$ \\
8 & $21(100 \%)$ & $0(0 \%)$ & $0(0 \%)$ \\
9 & $20(95 \%)$ & $1(5 \%)$ & $0(0 \%)$ \\
10 & $17(80 \%)$ & $2(10 \%)$ & $2(10 \%)$ \\
Jumlah & 200 & 5 & 5 \\
Rata-rata & $96 \%$ & $2 \%$ & $2 \%$
\end{tabular}


Desy A. dan Nurhapsari : Penguatan Keluarga Sakinah Bagi Ibu Muda

Berdasarkan tabel di atas, menunjukkan 96\% setuju, ibu muda memahami tentang hak dan kewajibannya sebagai perempuan dalam perspektif Islam, sedangkan $2 \%$ ragu-ragu, tentang laki-laki dan perempuan dalam perspektif Islam memiliki hak dan kewajiban yang sama, sedangkan $2 \%$ tidak setuju menunjukkan kurangnya pemahaman terkait materi dalam Islam perkara persaksian wanita, warisan, pemimpin dimana laki-laki dan wanita diperlakukan berbeda.

\section{Simpulan dan Saran}

\section{Simpulan}

Berdasarkan hasil analisis temuan penelitian di atas, maka dapat ditarik beberapa kesimpulan sebagai berikut :

a. Tingkat pemahaman ibu muda terhadap materi hak dan kewajiban perempuan dalam perspektif islam menunjukkan peningkatan pemahaman dalam aspek kognitif sebesar $96 \%$.

b. Baiknya partisipasi ibu muda di Kecamatan Umbulharjo, telah cukup berhasil merubah persepsi dan pandangan ibu muda yang bersifat pragmatik, sebab perlu disadari proses merubah pandangan tentang konsep keluarga sakinah memerlukan waktu yang cukup lama, dan membutuhkan kerjasama semua pihak. Namun demikian tindakan dalam pengabdian ini merupakan langkah awal yang baik, dalam upaya merintis model penguatan keluarga sakinah dengan membangun kesadaran melalui terbukanya ruang dialog antara pandangan ibu muda yang kontraproduktif terhadap 
Desy A. dan Nurhapsari : Penguatan Keluarga Sakinah Bagi Ibu Muda

tujuan pernikahan, menjadi pandangan-pandangan yang lebih positif untuk terciptanya keluarga sakinah. Tindakan yang dilakukan kepada ibu muda usia pernikahan 1-5 tahun, dalam penelitian ini memperoleh sambutan yang luar biasa dan partisipasi yang signifikan baik dari peserta dampingan, lembaga social keagamaan, dan masyarakat terkait pentingnya pembinaan perkawinan pasca menikah. Sebagai sebuah proses pemberdayaan penguatan, tindakan yang dilakukan dalam penelitian ini dimaksudkan untuk sebuah jangka pendek yang secara instant hasilnya dapat dilihat, tetapi sebuah rintisan dan upaya memberikan stimulus, agar ada model penguatan keluarga sakinah dari sisi konsep, dan adanya program pembinaan pasca menikah sehingga, ibu-ibu muda akan dioptimalkan fungsinya agar menjadi center integrated community development.

\section{Saran}

Untuk keberlanjutan proses pemberdayaan terhadap ibu muda di Kecamatan Umbulharjo, Kota Yogyakarta, maka saran dan rekomendasi pengabdian ini adalah

a. Persoalan perceraian yang meningkat dari tahun ke tahun, menunjukkan masih minimnya tingkat kesadaran masyarakat terhadap konsep keluarga sakinah, mawaddah, warahmah. Untuk membuat model Penguatan keluarga sakinah, maka diperlukan keberpihakan yang jelas dari pemerintah, lembaga social keagamaan dalam memberikan perhatian yang serius terhadap perlunya pembinaan pasca menikah sebagai bentuk proteksi dan dibuat regulasi atau 
Desy A. dan Nurhapsari : Penguatan Keluarga Sakinah Bagi Ibu Muda

kegiatan rutin yang dapat dilakukan secara kontinuitas, sehingga dapat menurunkan angka perceraian di daerah perkotaan.

b. Ada fakta bahwa masih minimnya pemahaman ibu muda terhadap konsep keluarga sakinah, terutama masih banyaknya persoalan rumah tangga yang menimbulkan konflik pada usia pernikahan 1-5 tahun. Hal ini dapat menjadi pemicu pada perceraian, tingkat kekerasan rumah tangga dan sebagainya. Untuk itu perlu dibuat kebijakan khusus berupa pembuatan modul keluarga sakinah, dan pola pembinaan keluarga perlu dilakukan dari tingkat majelis taklim hingga tingkat pemerintah.

Hasil eksplorasi dan tindakan yang telah dilakukan dan dirintis dalam penelitian ini, dapat dijadikan informasi awal dalam menyusun rencana program pembinaan bagi pemerintah, khususnya bagi pemerintah di Kecamatan Umbulharjo 
Desy A. dan Nurhapsari : Penguatan Keluarga Sakinah Bagi Ibu Muda

\section{DAFTAR PUSTAKA}

Ahmad Mahmudi, dkk. 2003. Penelitian Aksi Partisipatoris, sebuah Pengantar. SUSDEC. Yogyakarta.

Rahmat Hakim. 2000. Hukum Perkawinan Islam untuk IAIN, STAIN, PTAIS. cet. ke-I Pustaka Setia. Bandung.

Departemen Agama RI. 1993. Al-Qur'an dan Terjemahnya. Surya Cipta Aksara. Surabaya.

Dewan penyusun ensiklopedi Islam. 1993. "Sakinah", EnsiklopediIslam. Cet.I. jilid I.

Ibnu Musthafa.1993. Keluarga Islam Menyongsong abad 21. Bandung: Al-Bayan.

Ismail Widjaja, (ed.),1987. Panduan KB. Mandiri. Jakarta: PT. Falwa Arika.

Lubis Salam,t.th. Menuju Keluarga Sakinah. Surabaya: Terbit terang.

Mikkelsen. 2011. Metode Penelitian Partisipatoris dan Upaya Pemberdayaan; Panduan bagi Praktisi Lapangan, Jakarta: Yayasan Obor Indonesia.

Pusat penyusunan dan pengembangan bahasa.1990. Kamus besar bahasa Indonesia. Jakarta: Balai Pustaka, Cet.3.

Dadan Muttaqien,dkk. 1993.Peradilan agama dan kompilasi hukum islam dalam tata hukum Indonesia. Yogyakarta: UII Press.

Susi Bawarni dan Arin Mariani. 2000. Potret Keluarga Sakina.

Surabaya: Media Idaman Pers, Cet. II. 